\title{
Effect of Foliar Spray by Different Zinc Oxide Nanoparticles Concentrations at Various Growth Stages on Grain Yield and its Components of Maize
}

\author{
Abd El-Rahman, K.A.; E.A. Teama; F.M. Fathy and E.G. Abdelaziz \\ Agronomy Dept., Agric. Fac., Assiut Univ., Egypt \\ Received on: $18 / 8 / 2020$ \\ Accepted for publication on: 27/8/2020
}

\begin{abstract}
A field experiment was carried out during 2017 and 2018 seasons at the Agronomy Department Experimental Farm, Agriculture Faculty, Assiut University to study the effect of foliar spray time by different zinc oxide nanoparticles concentrations ( $\mathrm{ZnO}$ NPs) on production of maize. The experiment was laid out in randomized complete block design (RCBD) using strip plot arrangement with three replications. Zinc oxide nanoparticles concentration (tap water without $\mathrm{ZnO}$ NPs (control), 100, 200 and $300 \mathrm{ppm}$ ) were allocated horizontally, while, application time (8-10 leaves, tasseling and grain filling stages) were arranged vertically. Results show that zinc oxide nanoparticles concentrations did not affected significantly on all the studied traits in the both seasons, Furthermore, the foliar spray time had a significant effect on grain yield fed ${ }^{-1}$ in the both season, grains weight plant in the first season only and number of grains row $^{-1}$ in the second season only. Moreover, the interaction between studied zinc nanoparticles concentrations and applications time in this respect failed to be significant at 5\% level of probability in the two growing seasons. Whatever, the highest grain yield fed. ${ }^{-1}$ mean value in the first season $(3090.00 \mathrm{~kg})$ was recorded from maize plants which were sprayed by $100 \mathrm{ppm}$ of zinc oxide nanoparticles ( $\mathrm{ZnO} \mathrm{NPs}$ ) at tasseling stage, while the corresponding mean value in the second season $(3846.00 \mathrm{~kg})$ was achieved from maize plants which were sprayed by $200 \mathrm{ppm}$ zinc oxide nanoparticles at 8-10 leaves stage.
\end{abstract}

Keywords: Zinc Oxide nanoparticles, Growth stages, Grain yield and its components, Maize.

\section{Introduction}

Maize (Zea mays L.), it is widely cultivated throughout the world and has the highest production among all the cereals, is one of the most important cereal crops of the world and contributes to food security in almost all the developing countries. Maize, also known as "queen of cereals" is by far the largest component of global coarsegrain trade and its importance lies in the fact that it is not only utilized for human food and animal feed but at the same time it is also widely used for corn starch industry, corn oil production, baby corns etc. The crop has tremendous genetic variability, which enables it to thrive in tropical, sub-tropical and temperate climates. In Egypt, maize ranks the second after wheat amongst cereal crops grown in Egypt with regard the harvested area and production. According to FAOSTAT data base, Egypt (2018) harvested 935,778 hectare of maize and produced about 7.8 million tons of grains, 
with an average yield of $7.801 \mathrm{tha}^{-1}$ (FAOSTAT, 2020). The local of consumption of maize in Egypt is about 16 million tons. So, Egypt imports every year about nine million tons of maize grains.

The, increasing maize production to reduce the gap between production and consumption are the strategic aim. Therefore, a great attention should be paid to overcome or minimize the gap between maize production and consumption, thus increasing production per unit area appears to be the main objective of reducing the maize gap. Increasing maize yield per unit area could be attained by cultivating high-yielding hybrids and implement recommended cultural practices. The productivity and quality of maize depends on several factors like climate, agronomic management practices, varietal response, soil type etc. The response of different maize genotypes to zinc fertilization can support the expression of $\mathrm{Zn}$ efficient and $\mathrm{Zn}$-inefficient genotypes.

Zinc $(\mathrm{Zn})$ is considered an essential micronutrient which plays very important role in plant metabolism by influencing the activities of hydrogenase and carbonic anhydrase, stabilization of ribosomal fractions and synthesis of cytochrome, plant enzymes activated, carbohydrate metabolism, maintenance of the integrity of cellular membranes, protein synthesis, regulation of auxin synthesis and pollen formation, regulation and maintenance of the gene expression required for the tolerance of environmental stresses in plants (Hafeez et al., 2013).

Nanoparticle is defined based on the size at which fundamental properties differ from those of the corresponding bulk material (Banfield and Zhang, 2001). Nanoparticles overlap in size with colloids, which ranges from $1 \mathrm{~nm}$ to $1 \mathrm{~mm}$ in diameter (Buffle, 2006). Novel properties that differentiate nanoparticles from the bulk material typically develop at a critical length scale of under $100 \mathrm{~nm}$. The "novel properties" mentioned are entirely dependent on the fact that at the Nano-scale, the physics of nanoparticles mean that their properties are different from the properties of the bulk material. Particle size may affect agronomic effectiveness of $\mathrm{Zn}$ fertilizers. Decreased particle size results in increased number of particles per unit weight of applied $\mathrm{Zn}$. Decreased particle size also increases the specific surface area of a fertilizer, which should increase the dissolution rate of fertilizers with low solubility in water such as zinc oxide (Mortvedt, 1992).

Foliar application of $\mathrm{Zn}$ reduces the micronutrient deficiencies and it is an efficient method because nutrients are easily absorbed through leaves and is best option to compensate micronutrient deficiencies in shorter period.

A Few studies have investigated the effects of nanoparticles on corn growth. Among the metal oxides, zinc oxide nanoparticles have attracted attention due to their extensive properties. Zinc oxide is recognized as a safe substance by the United States Food and Drug Administration. Zinc salts are used 
in the treatment of zinc deficiency in humans. The antimicrobial effects of metal nanoparticles, including zinc oxide nanoparticles, have been noted in recent years. The considerable antimicrobial effect and low cost of zinc oxide nanoparticles have led to them being considered for application in the food industry to reduce bacterial growth (Pandeye et al., 2010).

So, the objective of this study was to elucidate the effect of foliar spray by different zinc oxide nanoparticles concentrations on grain yield and its components of maize.

\section{Materials and Methods}

A field experiment was carried out during 2017 and 2018 seasons at the Agronomy Department Experimental Farm, Agriculture Faculty, Assiut University to study the effect of foliar spray time by different zinc oxide nanoparticles concentrations ( $\mathrm{ZnO}$ NPs) on production of maize. The soil structure of the experimental site is clay, comprising of $42.60 \%$ clay, $30.40 \%$ silt and $27 \%$ sand with $\mathrm{pH}$ of 8.02 and EC $0.74 \mathrm{dsm}^{-1}$.

\section{Experimental treatments and de- sign:}

The experiment was laid out in randomized complete block design (RCBD) using strip plot arrangement with three replications. Zinc oxide nanoparticles concentration (tap water without $\mathrm{ZnO}$ NPs (control), 100,200 and $300 \mathrm{ppm}$ ) were allocated horizontally, while, application time (8-10 leaves, tasseling and grain filling stages) were arranged vertically. Each experimental unit area was $10.5 \mathrm{~m}^{2}$.

\section{Cultural practices:}

White single cross Hybrid (S.C.128) grains were hand sown on $6^{\text {th }}$ and $11^{\text {th }}$ June in the first and second seasons, respectively. Grains were sown in rows $80 \mathrm{~cm}$ apart in hills spaced $25 \mathrm{~cm}$. Plants were thinned after complete emergence before the first irrigation leaving one plant per hill. Maize plants were sprayed by the certain concentration of $\mathrm{ZnO}$ NPs at the mentioned stages. The preceding winter crop was wheat in the both seasons. All other recommended cultural practices for maize crop were done in the both seasons.

\section{Measured traits:}

At harvest (after 120 days from planting), random samples of five guarded plants from each experimental unit were taken at random to determine the following characters: Number of rows ear ${ }^{-1}$, grains number row $^{-1}$, 100-grain weight $(\mathrm{g})$, grain weight plant ${ }^{-1}$ as well as grains yield ( $\mathrm{kg} / \mathrm{fed}$.): It was determined by the weight of grains per kilograms adjusted to $15.5 \%$ moisture content of each plot, then converted to $\mathrm{kg} / \mathrm{fed}$.

\section{Statistical analysis:}

All collected data were analyzed with analysis of variance (ANOVA) Procedures, using the SAS Statistical Software Package v.9.2 (SAS, 2008). Differences between means were compared by the least significant difference (LSD) at $5 \%$ level of significant (Gomez and Gomez, 1984).

\section{Results and Discussion}

\section{1- Number of rows ear ${ }^{-1}$}

The illustrated data in Table 1 focus that the tested zinc oxide 
nanoparticles concentrations failed to exert any significant influence at $5 \%$ level of probability on number of rows ear ${ }^{-1}$ of maize in the two growing seasons. Whatever, the highest mean values of rows number ear ${ }^{-1}$ trait (14.01 and 13.03 in the first and second seasons, respectively) were obtained from maize plants which were sprayed by tap water (control) in the first season and from maize plants which were sprayed by $100 \mathrm{ppm}$ of zinc oxide nanoparticles (ZnO NPs) in the second season. In addition, increasing $\mathrm{ZnO}$ NPs concentration than 100 ppm or non- ZnO NPs application (control) led to decrease in number of rows ear ${ }^{-1}$ in the both seasons.

Table 1. Effect of Zinc Nanoparticles concentrations, application time and their interaction on maize rows number ear $^{-1}$ in 2017 and 2018 seasons.

\begin{tabular}{|c|c|c|c|c|c|c|c|c|}
\hline Seasons & \multicolumn{4}{|c|}{2017} & \multicolumn{4}{|c|}{2018} \\
\hline \multirow{2}{*}{\begin{tabular}{|c|} 
Zinc \\
Nanoparticles concentra- \\
tions $(C$, ppm $)$
\end{tabular}} & \multicolumn{3}{|c|}{ Application time (T) } & \multirow[b]{2}{*}{ Mean } & \multicolumn{3}{|c|}{ Application time (T) } & \multirow[b]{2}{*}{ Mean } \\
\hline & $\begin{array}{c}8-10 \\
\text { leaves }\end{array}$ & Tasseling & $\begin{array}{l}\text { Grain } \\
\text { filling }\end{array}$ & & $\begin{array}{c}8-10 \\
\text { leaves }\end{array}$ & Tasseling & $\begin{array}{l}\text { Grain } \\
\text { filling }\end{array}$ & \\
\hline Control & 14.15 & 13.60 & 14.30 & 14.01 & 12.20 & 13.07 & 13.05 & 12.77 \\
\hline 100 ppm & 13.60 & 13.70 & 14.20 & 13.83 & 13.10 & 12.90 & 13.10 & 13.03 \\
\hline 200 ppm & 13.90 & 13.20 & 13.80 & 13.63 & 12.80 & 12.52 & 12.30 & 12.54 \\
\hline 300 ppm & 13.85 & 13.85 & 13.40 & 13.70 & 12.52 & 12.75 & 12.75 & 12.67 \\
\hline Mean & 13.87 & 13.58 & 13.92 & $\begin{array}{ll}--- \\
\end{array}$ & 12.65 & 12.81 & 12.80 & $\begin{array}{ll}---- \\
\end{array}$ \\
\hline F test and L.S.D 0.05 & \multicolumn{2}{|c|}{ F test } & \multicolumn{2}{|c|}{ L.S.D 0.05} & \multicolumn{2}{|c|}{ F test } & \multicolumn{2}{|c|}{ L.S.D 0.05 } \\
\hline C & \multicolumn{2}{|c|}{ N.S } & \multicolumn{2}{|c|}{---} & \multicolumn{2}{|c|}{ N.S } & \multicolumn{2}{|c|}{---- } \\
\hline $\mathbf{T}$ & \multicolumn{2}{|c|}{ N.S } & \multicolumn{2}{|c|}{$\begin{array}{l}--- \\
\end{array}$} & \multicolumn{2}{|c|}{ N.S } & \multicolumn{2}{|c|}{---- } \\
\hline $\mathbf{C X ~ T}$ & \multicolumn{2}{|c|}{ N.S } & \multicolumn{2}{|c|}{---- } & \multicolumn{2}{|c|}{ N.S } & \multicolumn{2}{|c|}{----- } \\
\hline
\end{tabular}

Where, N.S mean non- significant at $5 \%$ level of probability

These finding are in a good line with those obtained by Similar trend was observed by Afshar et al. (2014), Tarafdar et al. (2014), Ghasal et al. (2017), Ghasemi et al. (2017), Kandil and Marie (2017) and Makarem et al. (2019).

Also, the presented data in Table 1 denote that the number of rows ear $^{-1}$ of maize did not reacted significantly at 5\% level of probability to application time of zinc oxide nanoparticles in the two growing seasons. Whatever, when application was done at late growth stages at grain filling in first season or in tasseling growth stage at in the first season it is increase number of rows ear $^{-1}$ than the other studied applications time. Moreover, number of rows ear $^{-1}$ were $13.87,13.58$ and
13.92 row ear ${ }^{-1}$ in the first season as the result of zinc application at 8-10 leaves, tasseling and grain filling stages, respectively being, 12.65 , 12.81 and 12.80 row ear $^{-1}$ in the second season in the same order. These findings are in a good line with those obtained by Farnia and Omidi (2015) and Amanullah et al. (2016).

Furthermore, the data exhibited in Table 1 show that the interaction between studied zinc nanoparticles concentrations and applications time in this respect failed to be significant at 5\% level of probability in the two growing seasons. Whatever, the highest number of rows ear ${ }^{-1}$ mean value (14.30 row ear ${ }^{-1}$ in the first season) was recorded from maize plants 
which were sprayed by tap water (control) at grain filling stage while, the corresponding mean value in the second season $\left(13.10\right.$ row $\left.^{-1}{ }^{-1}\right)$ was achieved from maize plants which were sprayed by $100 \mathrm{ppm}$ zinc oxide nanoparticles at 8-10 leaves or grain filling stages.

\section{2- Grains number rows ${ }^{-1}$}

The illustrated data in Table 2 reveal that the tested zinc oxide nanoparticles concentrations failed to exert any significant influence at $5 \%$ level of probability on number of grains row $^{-1}$ of maize in the two growing seasons. Whatever, the highest mean values of grains number row $^{-1}$ trait (31.48 and 37.02) were obtained from maize plants which was sprayed by 100 and by $200 \mathrm{ppm}$ of zinc oxide nanoparticles ( $\mathrm{ZnO}$ NPs) in the first and second seasons, respectively. This is to be logic since the same trend was observed regarding ear length trait as mentioned before. These finding are in a good line with those obtained by Similar trend was observed by Afshar et al. (2014), Tarafdar et al. (2014), Ghasal et al. (2017), Ghasemi et al. (2017), Kandil and Marie (2017) and Makarem et al. (2019).

Here too, the presented data in Table 2 focus that the number of grains row $^{-1}$ of maize did not re- acted significantly at $5 \%$ level of probability to application time of zinc oxide nanoparticles in the first season. On the contrary, the studied zinc application times had a significant effect on number of grains row $^{-1}$ of maize in the second season. Thus, the highest mean value of grains number row $^{-1}$ in the second season (38.23 grain row $^{-1}$ ) was recorded from maize plants which were received zinc oxide nanoparticles at 8-10 leaves stage. These findings are in a good line with those obtained by Farnia and Omidi (2015) and Amanullah et al. (2016).

Moreover, the data exhibited in Table 2 show that the interaction between studied zinc nanoparticles concentrations and applications time in this respect failed to be significant at $5 \%$ level of probability in the two growing seasons. Whatever, the highest number of grains row $^{-1}$ mean value (35.40 grain row $^{-1}$ in the first season) was recorded from maize plants which were sprayed by 100 ppm of zinc oxide nanoparticles (ZnO NPs) at tasseling stage while, the corresponding mean value in the second season (39.40 grain row ${ }^{-1}$ ) was achieved from maize plants which were sprayed by $100 \mathrm{ppm}$ zinc oxide nanoparticles and tap water at 8-10 leaves stage. 
Table 2. Effect of Zinc Nanoparticles concentrations, application time and their interaction on maize grains number row $^{-1}$ in 2017 and 2018 seasons.

\begin{tabular}{|c|c|c|c|c|c|c|c|c|}
\hline \multirow{3}{*}{\begin{tabular}{l}
\multicolumn{1}{c}{ Seasons } \\
Zinc \\
Nanoparticles concentra- \\
tions (C, ppm)
\end{tabular}} & \multicolumn{4}{|c|}{2017} & \multicolumn{4}{|c|}{2018} \\
\hline & \multicolumn{3}{|c|}{ Application time (T) } & \multirow[b]{2}{*}{ Mean } & \multicolumn{3}{|c|}{ Application time (T) } & \multirow[b]{2}{*}{ Mean } \\
\hline & $\begin{array}{c}8-10 \\
\text { leaves }\end{array}$ & Tasseling & $\begin{array}{l}\text { Grain } \\
\text { filling }\end{array}$ & & $\begin{array}{c}8-10 \\
\text { leaves }\end{array}$ & Tasseling & $\begin{array}{l}\text { Grain } \\
\text { filling }\end{array}$ & \\
\hline Control & 30.95 & 28.55 & 28.95 & 29.48 & 39.40 & 35.20 & 34.63 & 36.41 \\
\hline 100 ppm & 27.85 & 35.40 & 31.20 & 31.48 & 39.40 & 34.40 & 34.50 & 36.10 \\
\hline 200 ppm & 30.75 & 32.30 & 30.60 & 31.21 & 38.70 & 35.41 & 36.97 & 37.02 \\
\hline 300 ppm & 33.10 & 32.90 & 28.30 & 31.43 & 35.45 & 35.10 & 35.60 & 35.38 \\
\hline Mean & 30.66 & 32.28 & 29.76 & $\begin{array}{ll}---- \\
\end{array}$ & 38.23 & 35.02 & 35.42 & $\begin{array}{ll}---- \\
\end{array}$ \\
\hline \multicolumn{2}{|l|}{ F test and L.S.D 0.05} & \multicolumn{2}{|l|}{ F test } & \multicolumn{2}{|c|}{ L.S.D 0.05} & \multicolumn{2}{|l|}{ F test } & L.S.D 0.05 \\
\hline \multicolumn{2}{|l|}{$\mathbf{C}$} & \multicolumn{2}{|l|}{ N.S } & \multicolumn{2}{|l|}{---} & \multicolumn{2}{|l|}{ N.S } & --- \\
\hline $\mathbf{T}$ & & \multicolumn{2}{|l|}{ N.S } & \multicolumn{2}{|l|}{--- } & \multicolumn{2}{|l|}{ * } & 3.29 \\
\hline $\mathbf{C X T}$ & & \multicolumn{2}{|l|}{ N.S } & \multicolumn{2}{|l|}{---- } & \multicolumn{2}{|l|}{ N.S } & ----- \\
\hline
\end{tabular}

Where, N.S and * mean non- significant and significant at 5\% level of probability

\section{3- Hundred- grain weight (g)}

The illustrated data in Table 3 denote that the tested zinc oxide nanoparticles concentrations failed to exert any significant influence at $5 \%$ level of probability on maize seed index in the two growing seasons. Whatever, the highest mean values of seed index trait (34.42 and $33.06 \mathrm{~g}$ in the first and second seasons, respectively) were obtained from maize plants which was sprayed by tap water (control). These finding are in a good line with those obtained by Afshar et al. (2014), Tarafdar et al. (2014), Ghasal et al. (2017), Ghasemi et al. (2017), Kandil and Marie (2017) and Makarem et al. (2019).

Furthermore, the presented data in Table 3 clear that the maize seed index did not reacted significantly at $5 \%$ level of probability to application time of zinc oxide nanoparticles in the two growing seasons. Whatever, when application was done at early growth stages in 8-10 leaves in the first season or in late growth stage at grain filling in the second season it is encourage maize to produce the heaviest grains. Moreover, seed index were $34.62,33.92$ and $33.18 \mathrm{~g}$ in the first season as the result of zinc application at 8-10 leaves, tasseling and grain filling stages, respectively being, 32.85, 30.67 and $32.87 \mathrm{~g}$ in the second season in the same order. These findings are in a good line with those obtained by Farnia and Omidi (2015) and Amanullah et al. (2016). 
Table 3. Effect of Zinc Nanoparticles concentrations, application time and their interaction on maize 100 grain weight $(\mathrm{g})$ in 2017 and 2018 seasons.

\begin{tabular}{|c|c|c|c|c|c|c|c|c|}
\hline \multirow{3}{*}{\begin{tabular}{l}
\multicolumn{1}{c|}{ Seasons } \\
Zinc \\
Nanoparticles concen- \\
trations $(\mathrm{C}, \mathrm{ppm})$
\end{tabular}} & \multicolumn{4}{|c|}{2017} & \multicolumn{4}{|c|}{2018} \\
\hline & \multicolumn{3}{|c|}{ Application time (T) } & \multirow[t]{2}{*}{ Mean } & \multicolumn{3}{|c|}{ Application time (T) } & \multirow[t]{2}{*}{ Mean } \\
\hline & $\begin{array}{l}8-10 \\
\text { leaves }\end{array}$ & Tasseling & $\begin{array}{l}\text { Grain } \\
\text { fill- } \\
\text { ing }\end{array}$ & & $\begin{array}{l}8-10 \\
\text { leaves }\end{array}$ & Tasseling & $\begin{array}{l}\text { Grain } \\
\text { fill- } \\
\text { ing }\end{array}$ & \\
\hline Control & 35.09 & 35.22 & 32.95 & 34.42 & 33.75 & 32.07 & 33.37 & 33.06 \\
\hline 100 ppm & 34.45 & 34.44 & 33.26 & 34.05 & 32.86 & 30.66 & 33.57 & 32.36 \\
\hline 200 ppm & 34.79 & 34.00 & 33.43 & 34.07 & 32.81 & 30.08 & 31.10 & 31.33 \\
\hline 300 ppm & 34.17 & 32.04 & 33.10 & 33.10 & 32.00 & 29.89 & 33.43 & 31.77 \\
\hline Mean & 34.62 & 33.92 & 33.18 & --- & 32.85 & 30.67 & 32.87 & $\begin{array}{ll}----- \\
\end{array}$ \\
\hline F test and L.S.D 0.05 & \multicolumn{2}{|l|}{ F test } & \multicolumn{2}{|c|}{ L.S.D 0.05 } & \multicolumn{2}{|l|}{ F test } & \multicolumn{2}{|c|}{ L.S.D 0.05} \\
\hline $\mathbf{C}$ & \multicolumn{2}{|l|}{ N.S } & \multicolumn{2}{|l|}{----} & \multicolumn{2}{|l|}{ N.S } & \multicolumn{2}{|l|}{----} \\
\hline $\mathbf{T}$ & \multicolumn{2}{|l|}{ N.S } & \multicolumn{2}{|l|}{---- } & \multicolumn{2}{|l|}{ N.S } & \multicolumn{2}{|l|}{$-\cdots$} \\
\hline C X T & \multicolumn{2}{|l|}{ N.S } & \multicolumn{2}{|l|}{---- } & \multicolumn{2}{|l|}{ N.S } & \multicolumn{2}{|l|}{----- } \\
\hline
\end{tabular}

Where, N.S mean non- significant at $5 \%$ level of probability

Here too, the data exhibited in Table 3 reveal that the interaction between studied zinc nanoparticles concentrations and applications time in this respect failed to be significant at $5 \%$ level of probability in the two growing seasons. Whatever, the highest seed index means values (35.22 and $33.75 \mathrm{~g}$ in the two respective seasons) were recorded from maize plants which were sprayed by tap water (control) at tasseling stage and at 8-10 leaves stage, in the first and second seasons.

\section{4- Grains weight plant $^{-1}(\mathrm{~g})$}

The illustrated data in Table 4 focus that the tested zinc oxide nanoparticles concentrations failed to show any significant influence at $5 \%$ level of probability on grains weight plant ${ }^{-1}$ of maize in the two growing seasons. Whatever, the highest mean values of grains weight plant $^{-1}$ trait (138.53 and $124.53 \mathrm{~g}$ in the first and second seasons, respectively) were obtained from maize plants which was sprayed by $300 \mathrm{ppm}$ of zinc oxide nanoparticles ( $\mathrm{ZnO}$ NPs) in the first season and from maize plants which were sprayed by 100 ppm of zinc ox- ide nanoparticles ( $\mathrm{ZnO} \mathrm{NPs}$ ) in the second season. This is to be logic since the same trend was observed regarding, number of rows ear ${ }^{-1}$ and grains number row ${ }^{-1}$ traits as mentioned before. These finding are in a good line with those obtained by Similar trend was observed by Afshar et al. (2014), Tarafdar et al. (2014), Ghasal et al. (2017), Ghasemi et al. (2017), Kandil and Marie (2017) and Makarem et al. (2019).

Moreover, the presented data in Table 4 denote that the application time of zinc oxide nanoparticles had a significant effect on grins weight plant $^{-1}$ trait in the first season only. While, the grins weight plant ${ }^{-1}$ of maize did not react significantly at $5 \%$ level of probability to application time of zinc oxide nanoparticles in the second season. Thus, the highest mean value of grains weight plant $^{-1}$ in the first season $(142.37 \mathrm{~g})$ was obtained from tasseling stage application time. In addition, grains weight plant $^{-1}$ were $125.63,142.37$ and $131.47 \mathrm{~g}$ in the first season as the result of zinc application at 8-10 leaves, tasseling and grain filling 
stages, respectively being, 130.20 , 100.63 and $107.27 \mathrm{~g}$ in the second season in the same order. These findings are in a good line with those obtained by Farnia and Omidi (2015) and Amanullah et al. (2016).

Furthermore, the data exhibited in Table 4 show that the interaction between studied zinc nanoparticles concentrations and applications time in this respect failed to be significant at $5 \%$ level of probability in the two growing seasons. Whatever, the highest grains weight plant ${ }^{-1}$ mean value in the first season (146.36 g) was recorded from maize plants which were sprayed by $300 \mathrm{ppm}$ of zinc oxide nanoparticles ( $\mathrm{ZnO} \mathrm{NPs}$ ) at tasseling stage while, the corresponding mean value in the second season $(146.77 \mathrm{~g})$ was achieved from maize plants which were sprayed by $100 \mathrm{ppm}$ zinc oxide nanoparticles at 8-10 leaves stage.

Table 4. Effect of Zinc Nanoparticles concentrations, application time and their interaction on maize grains weight plant $^{-1}$ (g) in 2017 and 2018 seasons.

\begin{tabular}{|c|c|c|c|c|c|c|c|c|}
\hline \multirow{3}{*}{\begin{tabular}{l}
\multicolumn{1}{c|}{ Seasons } \\
Zinc \\
Nanoparticles concen- \\
trations $(\mathrm{C}, \mathrm{ppm})$
\end{tabular}} & \multicolumn{4}{|c|}{2017} & \multicolumn{4}{|c|}{2018} \\
\hline & \multicolumn{3}{|c|}{ Application time (T) } & \multirow[b]{2}{*}{ Mean } & \multicolumn{3}{|c|}{ Application time (T) } & \multirow[b]{2}{*}{ Mean } \\
\hline & $\begin{array}{c}8-10 \\
\text { leaves }\end{array}$ & Tasseling & $\begin{array}{l}\text { Grain } \\
\text { filling }\end{array}$ & & $\begin{array}{c}8-10 \\
\text { leaves }\end{array}$ & Tasseling & $\begin{array}{l}\text { Grain } \\
\text { filling }\end{array}$ & \\
\hline Control & 137.83 & 137.73 & 132.30 & 135.95 & 112.39 & 81.34 & 91.96 & 95.23 \\
\hline 100 ppm & 112.45 & 146.08 & 130.19 & 129.57 & 146.77 & 110.98 & 115.86 & 124.53 \\
\hline 200 ppm & 115.86 & 139.32 & 130.55 & 128.57 & 128.75 & 101.54 & 107.14 & 112.47 \\
\hline 300 ppm & 136.38 & 146.36 & 132.87 & 138.53 & 132.89 & 108.67 & 114.13 & 118.56 \\
\hline Mean & 125.63 & 142.37 & 131.47 & $\begin{array}{ll}---- \\
\end{array}$ & 130.20 & 100.63 & 107.27 & ---- \\
\hline F test and L.S.D 0.05 & \multicolumn{2}{|l|}{$F$ test } & \multicolumn{2}{|c|}{ L.S.D 0.05} & \multicolumn{2}{|l|}{$F$ test } & \multicolumn{2}{|c|}{ L.S.D 0.05} \\
\hline $\mathrm{C}$ & \multicolumn{2}{|l|}{ N.S } & \multicolumn{2}{|l|}{---- } & \multicolumn{2}{|l|}{ N.S } & \multicolumn{2}{|l|}{$-\cdots$} \\
\hline $\mathbf{T}$ & \multicolumn{2}{|l|}{$*$} & \multicolumn{2}{|l|}{1.75} & \multicolumn{2}{|l|}{ N.S } & \multicolumn{2}{|l|}{---- } \\
\hline $\mathbf{C X ~ T}$ & \multicolumn{2}{|l|}{ N.S } & \multicolumn{2}{|l|}{---- } & \multicolumn{2}{|l|}{ N.S } & \multicolumn{2}{|l|}{----- } \\
\hline
\end{tabular}

Where, N.S and * mean non- significant and significant at $5 \%$ level of probability

\section{5- Grains yield fed. ${ }^{-1}(\mathrm{Kg})$}

The illustrated data in Table 5 reveal that the tested zinc oxide nanoparticles concentrations failed to show any significant influence at $5 \%$ level of probability on grains yield fed. $^{-1}$ of maize in the two growing seasons. Whatever, the highest mean values of grains yield fed. ${ }^{-1}(2729.01$ and $2759.01 \mathrm{~kg}$ in the first and second seasons, respectively) were obtained from maize plants which was sprayed by 200 ppm of zinc oxide nanoparticles (ZnO NPs) in the first season and from maize plants which were sprayed by tap water (control) in the second season. This is to be logic since the same trend was observed regarding number of rows ear ${ }^{-1}$, grains number row $^{-1}$ and grain weight plant $^{-1}$ traits as mentioned before. These finding are in a good line with those obtained by Similar trend was observed by Afshar et al. (2014), Tarafdar et al. (2014), Ghasal et al. (2017), Ghasemi et al. (2017), Kandil and Marie (2017) and Makarem et al. (2019). 
Table 5. Effect of Zinc Nanoparticles concentrations, application time and their interaction on maize grains yield fed.-1 (kg) in 2017 and 2018 seasons.

\begin{tabular}{|c|c|c|c|c|c|c|c|c|}
\hline \multirow{3}{*}{\begin{tabular}{|l|}
\multicolumn{1}{|c|}{ Seasons } \\
Zinc \\
Nanoparticles con- \\
centrations (C, \\
ppm)
\end{tabular}} & \multicolumn{4}{|c|}{2017} & \multicolumn{4}{|c|}{2018} \\
\hline & \multicolumn{3}{|c|}{ Application time (T) } & \multirow[b]{2}{*}{ Mean } & \multicolumn{3}{|c|}{ Application time (T) } & \multirow[b]{2}{*}{ Mean } \\
\hline & 8-10 leaves & Tasseling & $\begin{array}{l}\text { Grain } \\
\text { filling }\end{array}$ & & $\begin{array}{c}8-10 \\
\text { leaves }\end{array}$ & Tasseling & $\begin{array}{c}\text { Grain fill- } \\
\text { ing }\end{array}$ & \\
\hline \begin{tabular}{|l|} 
Control \\
\end{tabular} & 2400.00 & 2767.50 & 2385.00 & 2517.51 & 3222.00 & 2326.50 & 2728.50 & 2759.01 \\
\hline $100 \mathrm{ppm}$ & 2257.50 & 3090.00 & 2430.00 & 2592.51 & 3060.00 & 1602.00 & 2385.00 & 2349.00 \\
\hline $200 \mathrm{ppm}$ & 2586.00 & 2775.00 & 2826.00 & 2729.01 & 3846.00 & 1738.50 & 2144.55 & 2576.34 \\
\hline $300 \mathrm{ppm}$ & 2331.00 & 2619.00 & 2040.00 & 2330.01 & 2959.20 & 1738.50 & 2005.50 & 2576.34 \\
\hline Mean & 2393.64 & 2812.89 & 2420.25 & & 3271.80 & 2538.00 & 2315.88 & ----- \\
\hline F test and L.S.D 0.05 & \multicolumn{2}{|l|}{ F test } & \multicolumn{2}{|c|}{\begin{tabular}{|l|l|} 
L.S.D 0.05 \\
\end{tabular}} & \multicolumn{2}{|l|}{ F test } & \multicolumn{2}{|l|}{\begin{tabular}{|l|} 
L.S.D 0.05 \\
\end{tabular}} \\
\hline $\mathrm{C}$ & \multicolumn{2}{|l|}{ N.S } & \multicolumn{2}{|l|}{----} & \multicolumn{2}{|l|}{ N.S } & \multicolumn{2}{|l|}{ |--- } \\
\hline $\mathbf{T}$ & \multirow{2}{*}{\multicolumn{2}{|c|}{$*$}} & \multicolumn{2}{|l|}{117.50} & \multirow{2}{*}{\multicolumn{2}{|c|}{$*$}} & \multicolumn{2}{|l|}{242.50} \\
\hline CX T & & & \multicolumn{2}{|l|}{ 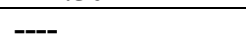 } & & NS & \multicolumn{2}{|l|}{--} \\
\hline
\end{tabular}

Where, N.S and * mean non- significant and significant at $5 \%$ level of probability

Moreover, the presented data in Table 5 denote that the application time of zinc oxide nanoparticles had a significant effect on grins weight plant $^{-1}$ trait in the both seasons. Thus, the highest mean values of grain yield fed. ${ }^{-1}$ (2812.89 and $3271.80 \mathrm{~kg}$ in the first and second seasons, respectively) were obtained from tasseling stage application time in the first season but, in the second season was obtained when application was done at 8-10 leaves stage. In addition, grain yield fed. $^{-1}$ were $2393.64,2812.89$ and $2420.25 \mathrm{~kg}$ in the first season as the result of zinc application at 8-10 leaves, tasseling and grain filling stages, respectively being, 3271.80 , 2538.00 and $2315.88 \mathrm{~kg}$ in the second season in the same order. These findings are in a good line with those obtained by Farnia and Omidi (2015) and Amanullah et al. (2016).

Furthermore, the data exhibited in Table 5 show that the interaction between the studied zinc nanoparticles concentrations and applications time in this respect failed to be sig- nificant at 5\% level of probability in the two growing seasons. Whatever, the highest grain yield fed. ${ }^{-1}$ mean value in the first season $(3090.00 \mathrm{~kg})$ was recorded from maize plants which were sprayed by 100 ppm of zinc oxide nanoparticles (ZnO NPs) at tasseling stage while, the corresponding mean value in the second season $(3846.00 \mathrm{~kg})$ was achieved from maize plants which were sprayed by 200 ppm zinc oxide nanoparticles at 8-10 leaves stage.

\section{References}

Afshar, I.; R. Akbar and S. Minoo (2014). Comparison of the effects of spraying different amounts of nano $\mathrm{ZnO}$ and bulk $\mathrm{ZnO}$ on wheat. Int. J. Plant, Animal and Env., Sci., 4: 688-693.

Amanullah, A.S., A. Iqball and S. Fahad (2016). Foliar Phosphorus and Zinc Application Improve Growth and Productivity of Maize (Zea mays L.) Under Moisture Stress Conditions in Semi-Arid Climates. J Microb Biochem Technol, an open access journal. Vol. 8(5): 433- 439. 
Banfield, J.F. and H. Zhang (2001). Nanoparticles in the Environment. In "Nanoparticles and the Environment" (J. F. Banfield and A. Navorotsky, Eds,), Mineralogical Society of America, Washington, DC Chapter 1. pp. $1-58$.

Buffle. J.(2006). The key role of environmental colloids/ nanoparticles for the sustainability of life. Environ. Chem., 3: 155-158.

FAOSTAT http://www.fao.org/faostat/en/\#h ome.

Farnia, A. and M.M. Omidi (2015). Effect of nano-zinc chelate and nano-biofertilizer on yield and yield components of maize (Zea mays L.), under water stress condition. Indian J. of Nat. Sci., 5(29): 4614-4624.

Ghasal P.C.; Y.S. Shivay; V. Pooniya; M. Choudhary and R.K. Verma (2017). Response of wheat genotypes to zinc fertilization for improving productivity and quality, Archives of Agron. and Soil Sci., 63(11): 1597-1612.

Ghasemi, M; G.N. Mohammadi; H. Madani; H.R. Mobasser and M. Nouri (2017). Effect of foliar application of zinc nano oxide on agronomic traits of two varieties of rice (Oryza sativa L.). Crop Res. 52 (6): 195-201.

Gomez, K.A. and A.A. Gomez (1984). Statistical Procedures for Agricultural Research. $2^{\text {nd }}$ Edn., John
Wily and Sons, New York, pp: 68.

Hafeez, B.; Y.M. Khanif and M. Saleem (2013). Role of Zinc in Plant Nutrition- A Review. American J. Experimental Agric., 3(2): 374-391.

Kandil, E.E. and E.A.O. Marie (2017). Response of some wheat cultivars to Nano- mineral fertilizers and amino acids foliar application. Alexandria sci. exchange j., 38:53-68.

Makarem, H.; I.A. El-Far; E.A. Ali and M.T. Said (2019). Response of three bread wheat cultivars to foliar spray by some micro- nutrients Nano- Particles. Assiut J. Agric. Sci., 50 (4): 9-21.

Mortvedt, J.J. (1992). Crop response to level of water soluble zinc in granular zinc fertilizers. Fertilizer Res., 33: 249-255.

Pandey A.C., S. Sanjay, S. Yadav (2010). Application of $\mathrm{ZnO}$ Nanoparticlesin Influencing the Growth Rate of Cicer Arietinum. Journal of Experimental Nanoscience. 5(6):488-97.

SAS institute (2008). The SAS System for Windows, release 9.2. Cary NC: SAS institute.

Tarafdar, J.C.; R. Raliya; H. Mahawar and I. Rathore (2014). Development of zinc nano fertilizer to enhance crop production in pearl millet (Pennisetum americanum). Agricultural Research, 3(3): 257262. 


\section{تاثير الرش الورقي بتركيزات مختلفة من اكسيد الزنك النانومتري في مراحل نمو مختلفة علي

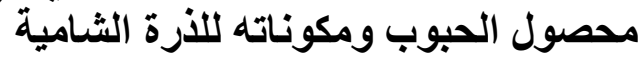 \\ كامل علي عبد الرحمن و المهدي عبد المطلب المهذي طعيمه و فتحي محمد فتحي وايناس جميل عبد} قسم المحاصبلـ كلية الزر اعة- جامعة اسيوطـ مصر

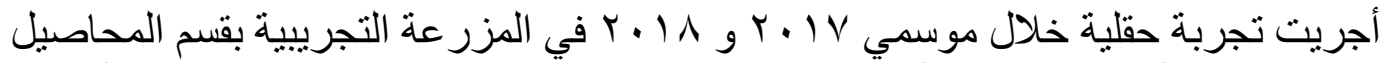

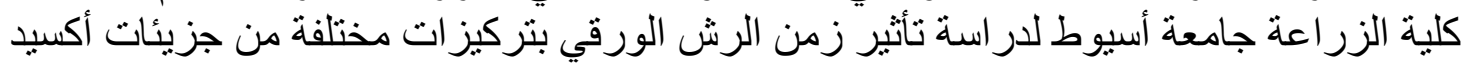

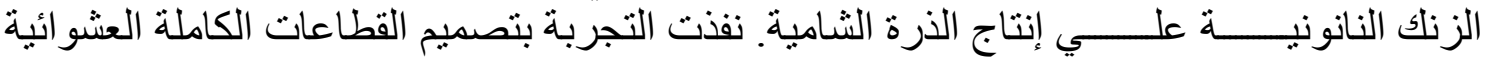

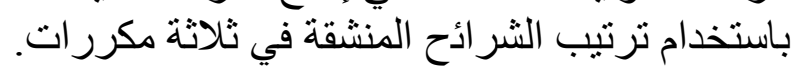

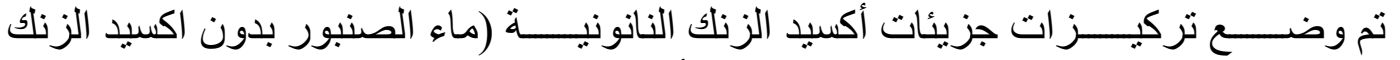

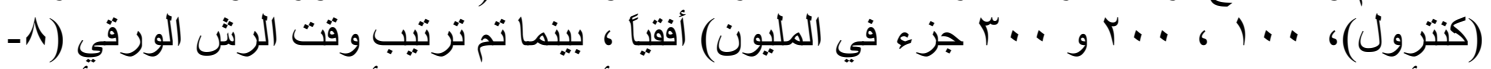

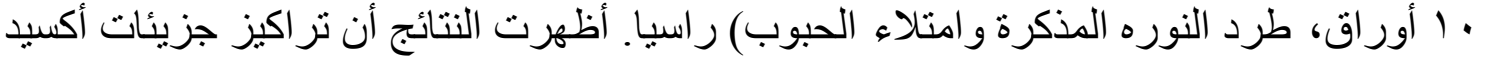

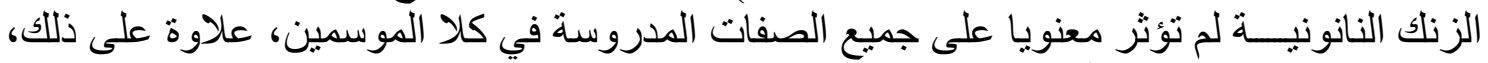

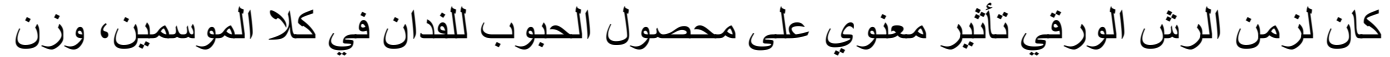

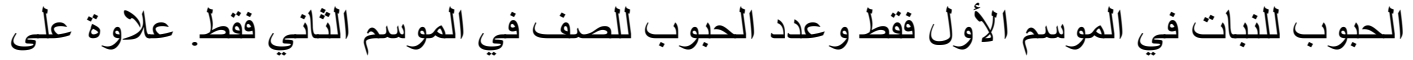

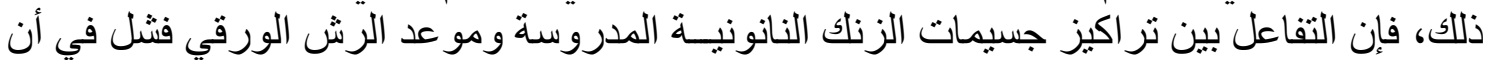

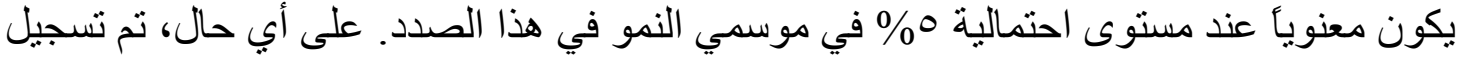

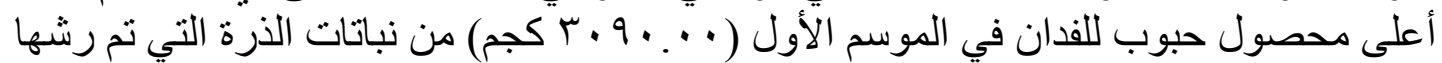

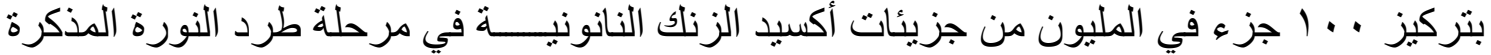

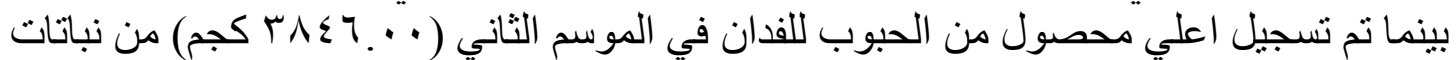

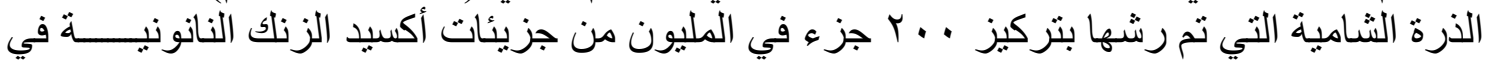

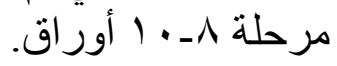

